\title{
POLITICAL ECONOMICS AND THE WEIMAR DISASTER
}

\author{
by \\ Roger B. Myerson \\ first version: July 1998 \\ final version: January 2004
}

\begin{abstract}
The treaty of Versailles and the Weimar constitution were written in 1919 with expert advice from John Maynard Keynes and Max Weber respectively. This paper considers how advances in political and economic theory since then could help to better understand the problems of Weimar and Versailles. The Weimar constitution's combination of a strong presidency with a proportional-representation legislature may be responsible for the breakdown of German parliamentary government, and may have facilitated the careers of extremist authoritarian politicians. The Versailles treaty's huge reparations bill created a war of attrition that encouraged Germans to cultivate the Depression and Nazism.
\end{abstract}

JEL Classification: N44. Keywords: Weimar constitution, Versailles treaty, reparations.

Author's address: Department of Economics, University of Chicago, 1126 East 59th Street, Chicago, IL 60637, USA.

E-mail: myerson@uchicago.edu

URL: http://home.uchicago.edu/ rmyerson/ 


\title{
POLITICAL ECONOMICS AND THE WEIMAR DISASTER
}

\author{
by Roger B. Myerson
}

\begin{abstract}
"His qualifications to speak on the economic aspects were indisputable... [but] on the other and vastly more important side of the problem he could judge no better than many others." Winston Churchill, referring to Keynes (quoted by Mantoux, 1946)
\end{abstract}

\section{History and theory}

The disaster of the Weimar Republic is one of the great tragedies of history. In 1919 at Weimar and Versailles, great national leaders with some of the best expert advisors of the day met to establish a new and better system for Germany and the world. But they made choices that somehow led to the one outcome that they most sought to avoid: the rise in Germany of the brutal and aggressive Nazi regime. To read the history of these times is to be haunted by the utter failure of the great leaders at these conferences. Why did they fail so badly to foresee the consequences of their decisions? Why did they misunderstand the dynamics of the political and economic systems that they were establishing?

I read the history of the Weimar disaster as a social scientist. The job of social scientists is to try to extend people's understanding of political and economic institutions where that understanding has been inadequate. So for us the Weimar disaster stands out as a case study for evaluating what (if anything) we have learned since then. Of course there is a temptation to draw simplistic lessons from history, by saying that choices which led to disaster in the past should be avoided when such situations arise in the future. But no two historical situations are exactly alike, and we cannot judge the similarity of alternatives in two different situations without some general conceptual structure and analytical theory. To really learn from history, we need good social theory. So I want to review the history of the Weimar disaster here with an eye on two questions for social science: Have our basic theories of political and economic systems advanced in any ways that could have offered better guidance during that fateful period of history? And what new research directions might offer more hope of such advances in the future?

I hope to show in this review that our ability to understand the subtleties of such problems has been enhanced by the new and broader scope of economic analysis that has followed 
advances in game-theoretic modeling. Useful game models to which I will refer include signaling games, dynamic threat games, and models of property-right enforcement. I will try to show that useful insights can be gained from analysis of political incentives under different constitutional structures. Above all, I want to show here that integrated analytical approaches to the study of political and economic competition can help to better understand the decisions that faced the leaders of Weimar and Versailles. The dynamics of the Weimar disaster were driven by complex interactions between political and economic factors, and theorists who specialize in only one side can easily miss the big picture. Thus, I have approached the Weimar history as a case study in the need for the kind of work that has been done in modern political economics, where we use game-theoretic models that can be applied equally well to analysis of political and economic competition.

\section{Macroeconomics and the Great Depression}

When we look for major advances in economics that could have been valuable for avoiding at least some of the great mistakes of the Weimar period, we find one area in which the existence of such advances has long been widely recognized: Macroeconomics. The follies of monetary contraction and budget surpluses in a period of high unemployment are now understood far better than in 1929, thanks to the work of macroeconomic theorists, beginning most prominently with John Maynard Keynes (1936). The rise of the Nazi party from a tiny fringe group to the largest party in Germany occurred during the worst years of the Great Depression, and the ranks of the party were swelled with masses of unemployed workers. There can be no question that the depression was one of the principal causes of the Nazi triumph. If German monetary and financial policies from 1929 to 1932 had followed the directions of modern macroeconomic theory, perhaps these conditions for Hitler's triumph could have been avoided. (For an exploration of such questions, see Ritschl, 1998.)

But without diminishing the importance of the macroeconomic factor, there is much more that we need to consider. Other democracies survived the Great Depression without turning to fascist dictators, which leads us to search for explanations as to why the German democracy failed when others did not. It is true that the depression was more severe in Germany than in other countries besides the United States, but American democracy survived. 
More importantly, the question of why the German depression was so severe may have a political answer. During the critical period from March 1930 to May 1932, the chancellor of Germany was Heinrich Bruening, a leader of the Catholic Center party. In his postwar memoirs, Bruening (1970) describes his economic policies during this period as being deliberately deflationary. By his own admission, Bruening raised taxes and cut public expenditure, deliberately driving the German economy into the worst of the depression, for the purpose of strengthening Germany's hand in international relations.

The central goal of his foreign policy was to obtain a suspension of the reparations payments that were demanded by the Allies in the treaty of Versailles. And indeed, during the deepening German economic crisis, the Allies in 1931 allowed a one-year moratorium on reparations payments, and then in July 1932 they agreed at last to permanently terminate all reparation demands on Germany. Only after July 1932 could the German government feel free to stimulate the economy, which may have been just in time to induce a macroeconomic upturn after Hitler took power six months later.

So we cannot simply view the Weimar disaster as a political event with economic causes. The lines of cause and effect may go both ways between the economic and political arenas. To fully understand the story, we need to look back both to German political history and to the international system established by the treaty of Versailles.

\section{German democratic traditions}

It has been suggested that the roots of the Nazi triumph should be found in particular German cultural traditions of authoritarianism and antisemitism. Obviously the Nazi movement drew from such traditions, and in particular the Nazi's choice of Jews as scapegoats was driven by ugly cultural traditions dating back into the middle ages. But to explain the fall of the Weimar Republic as a consequence of specifically German cultural traditions is to dismiss the possibility of learning anything from it that can be applied elsewhere.

After all, authoritarian traditions and antisemitism were not unique to Germany, as can be seen by comparison with the early history of the French Third Republic which began in 1871 . The French Third Republic is in many ways a remarkably close analogue to the Weimar Republic. Both the Weimar Republic of Germany and the Third Republic of France began with a 
humiliating military defeat by the other nation. The violent struggle of the Paris Commune was not less bloody than the riots that accompanied the birth of the Weimar Republic. The monarchist parties won a large majority of the seats in the first assembly of the Third Republic, and so it is hard to argue that authoritarian traditions were weaker in France. French antisemitism during the Dreyfus affair shook the foundations of the Third Republic and shocked the Viennese Herzl. And yet, during the Third Republic, democracy became more firmly rooted in France.

The ideal of democracy had been an important part of French intellectual tradition since 1789. But before the beginning of the Third Republic in 1871, the practice of democracy had found only limited application in France. The First Republic had degenerated rapidly into the Terror, and the Second Republic had survived only 4 years before being displaced by Napoleon III.

Germany first experimented with democracy in 1848. But more importantly, democratic elections played a serious role in the politics of the German Empire that preceded the Weimar Republic during the period 1871-1918. The history of the socialist movement gives remarkable evidence of the seriousness of democracy in Germany under Bismarck. Socialist organizations were illegal in Germany before 1890, but the German Empire also guaranteed political freedom to all candidates for seats in the Reichstag, and socialist candidates openly competed in Reichstag elections, getting about $10 \%$ of the vote and winning 24 seats in 1884 . (The Kaiser himself took a leading role in abolishing the anti-socialist laws in 1890 over the opposition of Bismarck; see Koch, 1984, page 172.)

Under the constitution of the German Empire, the chancellor was appointed by the Kaiser and responsible to him, but the Reichstag had control of the budget and legislation. Parliamentary leaders were excluded from the ministerial positions by a constitutional law against government officials serving in the Reichstag. As in British constitutional history, however, the power of the purse and the strength of popular electoral mandate gradually shifted power from the Kaiser towards Reichstag, so that by 1917 a new chancellor could take power only after negotiating a majority coalition in the Reichstag (Koch, 1984, page 228). Thus, from the perspective of German constitutional history, the resignation of the Kaiser and the founding of the Weimar Republic appeared as a natural evolutionary development, and not as the 
imposition of some foreign institutional form. The Weimar Republic began with a collection of well-established political parties that had emerged continuously from the Empire period.

\section{The Weimar constitution}

A National Assembly met in the town of Weimar in 1919, to establish a constitution for the new German Republic. The constitution was primarily written by a committee led Hugo Preuss, a legal and political theorist, with influential ideas being contributed by Robert Redslob and Max Weber (see Mommsen, 1984). Weber in particular was an active participant in the process of drafting the constitution, and his arguments for a strong presidency prevailed over others who wanted to imitate the French parliamentary system.

Weber advocated a constitution that would put supreme power in the hands of a strong individual leader who would derive his authority from the will of the people. (See Mommsen, 1984, chapter 9.) Weber distrusted party politicians, and viewed the legislature primarily as a body to remind the great leader of his need to answer to the people. Weber's concept was moderated by Redslob's conception of a government depending more equally on the separate powers of the President and the Reichstag.

The Weimar constitution established a Reichstag elected by a pure form of proportional representation, with a party getting one seat for every 60,000 votes that it got nationwide. The maximum term of the Reichstag was 4 years, but new Reichstag elections could also be called by the President at virtually any time. The German states had representation in a weak upper house, the Reichsrat, but a 2/3 majority in the Reichstag could override any objection by the Reichsrat. The President was also chosen by popular election, serving for a fixed term of 7 years, but a $2 / 3$ majority in the Reichstag could demand a new presidential election at any time. Under Article 48, the President and the chancellor could together issue decrees when public order was endangered, although these decrees could be rescinded on the demand of the Reichstag. The President could appoint and dismiss the chancellor and ministers, who could also be dismissed by a vote of the Reichstag. The President also had the power to submit any act of the Reichstag to a popular referendum, and such a referendum could also be called by a popular petition signed by $10 \%$ of the voters.

As Redslob recommended, the chancellor and ministers of the government were 
dependent simultaneously on both the President and the Reichstag, because both had power to dismiss the government. Shugart and Carey (1992) have observed that such presidentialparliamentary systems with dual cabinet responsibility can force the government into a deadlock when the president and legislature make co-equal conflicting demands on it, but the Weimar constitution gave a substantial advantage to the President in the case of such conflict. The Weimar President could appoint ministers alone and co-sign their decrees into law, and he could punish the Reichstag by calling new elections if it objected to either his ministers or their decrees. The Reichstag's countervailing power to dismiss the President with 2/3 majority had no application during the history of the Republic. In essence, the Weimar President had unrestricted power to direct the state as long as he could find support from at least $1 / 3$ of the Reichstag. So the most striking modification of Weber's ideas in the Weimar constitution was only that the President could not directly govern by himself, but had to entrust the daily control of government and patronage to the chancellor and other ministers. Also, a President who chose not to exercise this power could permit the Reichstag to control the government.

In most democracies that use proportional representation, it is applied in a moderated form with small districts and minimum thresholds which discourage the formation of small parties (see Taagepera and Shugart, 1989). Pure proportional representation as practiced in the Weimar Republic is much less common. Such extreme proportional representation facilitates the creation of many small parties that focus on special groups or narrowly defined ideological positions. In parliamentary systems, this centrifugal force is counterbalanced by the strong incentive of parliamentary parties to form a government, to enjoy the rewards of patronage. But in presidential systems, the power of the president greatly reduces the rewards that the legislative parties can expect from coalition formation. When legislative and presidential elections are concurrent, connections with strong presidential candidates may offer some electoral benefits to the largest parties, but legislative and presidential elections in the Weimar Republic were not concurrent. So a presidential system with extreme proportional representation in nonconcurrent legislative elections seems most likely to generate a plethora of legislative parties that focus on the special demands of their constituents and neglect the problem of formulating coherent national policy that can get broad popular support. (See Shugart and Carey, 1992, and Jones, 1995.) 
Under its first President, Friedrich Ebert of the SPD (the Socialist Party), the Weimar Republic established itself against the chaos of 8 uprisings by leftist extremists and 3 uprisings by rightist extremists, plus the traumatic invasion of the Ruhr district by the French in 1923 . Parliamentary control of the government was successfully exercised by shifting coalitions composed of socialist, Catholic, and bourgeois liberal parties. After Ebert's death in 1925, the retired general Paul von Hindenburg was elected President in a three-candidate run-off election, following the lack of any majority candidate at the first round.

Hindenburg did not at first try to undermine the principle of parliamentary formation, but he had a strong hostility to the SPD and worked to keep them out of the government (Kolb, 1988, page 74). After the May 1928 Reichstag elections, however, the SPD had almost 1/3 of the seats, and it was practically impossible to form a coalition without them, and so the last parliamentary coalition formed a government under the SPD leader Hermann Mueller. The partners in this coalition found it difficult to compromise over controversial questions of social policy (collective bargaining, unemployment insurance, and length of the work day), because of the conflicting hard-line demands of their various parties' members. By 1929, young and leftist SPD members had tilted the balance of opinion in the party against further participation in such coalitions. Opponents of parliamentary compromise in the SPD argued that, although the President might respond by forming a government without the consent of the Reichstag, socialist workers could always prevent a slide into dictatorship by calling a general strike, as had been done against the rightist Kapp putsch in 1919 (Koch, 1984, pages 289-291). So in March 1930, the last parliamentary coalition collapsed. Unfortunately, when the presidential government did in fact turn into a dictatorship a few years later, the will among socialist workers to organize a general strike had been broken by the long high unemployment of the depression. So the decision by the SPD to allow the end of the parliamentary system seems to have been a decisive turning point and a major strategical error (Kolb, 1988, page 82).

After the collapse of the parliamentary coalition in 1930, Hindenburg appointed Bruening of the Center party to form a government without the support of a parliamentary majority. The tough deflationary economic policies of the Bruening government, which contributed to the deepening depression, could then be implemented by presidential decree without the participation or endorsement of the Reichstag. The number of laws passed by the Reichstag 
decreased from 98 in 1930 to 5 in 1932, while the number of presidential decrees increased from 5 in 1930 to 66 in 1932 (Kolb, 1988, page 114). But this apparent failure of the parliamentary system may have been exactly what Weber had intended at the beginning: government under the supervision of one great leader who is responsible to the people alone.

The hard-line bargaining strategy of the SPD was echoed in 1932, when the Nazis were the largest party in the Reichstag and they also refused to participate in any government unless their leader was appointed as chancellor. At one point the leader of the left wing of the Nazi parliamentary faction, Gregor Strasser, considered an invitation to join von Schleicher's government as vice-chancellor, but Hitler quickly re-established discipline behind his all-ornothing policy. In this willingness of Reichstag members to choose obstructive posturing over direct participation in the power of government, we may see the effects of the Weimar constitution. If Weber wanted real power to lie in Presidency, then the Reichstag could only be reduced to a forum for expressing the protests of different interest groups. So from a Weberian perspective perhaps it was not dysfunctional to have legislative parties choosing to be advocates rather than participants in the government.

To see how constitutional structures can affect such party policies, a comparison with the French Fourth Republic may be instructive. The French Fourth Republic (1945-1958) is often cited as a failure among multiparty parliamentary democracies. But in at least one regard it showed some remarkable success in absorbing a movement that threatened to destroy it. In the French elections of 1951, the principal right-wing political party was the RPF (Rassemblement du Peuple Francais) led by Charles de Gaulle. De Gaulle was not Hitler, but De Gaulle's party was like Hitler's party in that both parties sought seats in the parliament with the announced goal of ending the multiparty parliamentary democracy and replacing its constitution. After the French 1951 election, however, the elected representatives of the RPF participated in parliamentary coalition-formation just like any other party. In the scornful words of de Gaulle, the RPF representatives went "to the soup" (Rioux, 1987, page 195), because the attractions of participating in the government were simply too strong to resist in the parliamentary system of the Fourth Republic. The Communists alone were excluded from Fourth-Republic coalitions, not by their own choice, but because other parties refused to accept them as partners.

The Boulangist threat to the French Third Republic offers another illustrative contrast 
with the Weimar Republic. The figure of General Boulanger in the Third Republic has remarkable parallels with that of Adolf Hitler in the Weimar Republic. They were both charismatic leaders of mass movements that threatened to overturn their Republics after the first decade of the Republic's existence. (The Boulangist movement peaked in 1889, 18 years after the founding of the Third Republic, while Hitler took power 14 years after the founding of the Weimar Republic.) Like Hitler, Boulanger had a remarkable ability to appeal to groups on both the left and right, and he exploited nationalist desires for revenge against the foreign power which had inflicted the previous humiliating defeat.

To stop Boulanger, the republicans used tactics of electoral reform. In the French election of 1889 , all seats were allocated in single-member districts, in contrast to the previous 1885 election where seats had been allocated to multiseat districts. (In the 1885 system, voters had as many noncumulable votes as there were seats, so that it was not a proportional representation system; see Cole and Campbell, 1989.) Furthermore, a new 1889 law prohibited a candidate from running in multiple districts, so that the Boulangists could not use Boulanger's name in more than one district (Mayeur and Riberioux, 1984, pages 133-136). In the 1889 election, the Boulangist candidates only got $9 \%$ of the vote, winning about $7 \%$ of the seats. Two years later, Boulanger committed suicide on the grave of his mistress.

This story of Boulanger suggests the hypothesis that authoritarian parties with a charismatic leader may have less appeal in single-member-district electoral systems than in multi-member list systems. Even voters who are attracted to an authoritarian leader may have misgivings about their own district's only representative being someone who is totally controlled by this leader, if other districts are likely to elect representatives who will be freer to advocate local interests in the legislature (whether directly on the floor of the legislature or in the legislative caucuses of a nonauthoritarian party). This argument may also explain why the followers of Vladimir Zhirinovsky in the 1993 Russian Duma elections were unable to match their large list vote with votes for single-member-district seats. Furthermore, any electoral system where voters vote for party lists, rather than for individual candidates, makes it easier for party leaders, who control renomination to the list, to maintain authority over the legislative representatives from their party (Carey and Shugart, 1995). From this perspective, we can see that the proportional representation system of the Weimar Republic was particularly well suited 
to the purposes of a party like the Nazis with their Fuehrer principle.

\section{The Paris peace conference and the treaty of Versailles}

In 1920, John Maynard Keynes burst into world prominence by his critique of the Paris peace conference, where he had served in the Supreme Economic Council as a deputy of the British Chancellor of the Exchequer. Keynes's book Economic Consequences of the Peace is a brilliant polemic against errors and excesses of the conference.

At the conference (as Keynes describes it) the Americans were led by Woodrow Wilson, who promised nonpunitive settlements and national self-determination in noble speeches, but who could not effectively focus on details of implementation. The French were led by the pragmatic Georges Clemenceau, who wanted to undo the German unification of 1870 and in particular hoped to separate the Rhineland (east of the Rhine) from the rest of Germany. The British were led by David Lloyd George, whose party had made electoral promises to demand full reparations from the Germans for the damages that they had done in the war. From these conflicting positions, the Allies produced a treaty with the following characteristics: Germany's territory was only marginally reduced, but Germany's eastern neighbors were partitioned into smaller units along ethnic lines; the strength of German military was severely limited; Germany was required to admit its guilt for the war and pay a large reparations bill whose full extent would be defined later; the Rhineland was to be occupied by Allied troops for 15 years; and the League of Nations was established as a forum to prevent future crises from escalating into war.

At the start of the Paris peace conference, Wilson anticipated that, after preliminary discussions among the Allies, they would negotiate with German representatives, and only thereafter should the terms of the final treaty be written. Lloyd George (1938, pages 720-721) reports that Wilson had reversed this position by the end of the conference. When the draft of the treaty was finally revealed to the Germans after months of negotiations among the Allies alone, Wilson felt that the treaty already represented a difficult compromise among many conflicting Allied views, and to alter it substantially in deference to German criticisms was to run the risk of having the whole fabric falling to pieces. In this way, the Paris peace talks were very different from the 1815 Congress of Vienna, where the leaders of the coalition against France set a durable framework for post-Napoleonic Europe with the active participation of Talleyrand, who could 
articulate the conditions needed to sustain a moderate regime in defeated France.

A fundamental goal for the Allies at the 1919 conference was the need to craft a peace settlement that would not stimulate German sentiments for revenge which could lead to another world war. Lloyd George reports (1938, pages 135 and 396) that this argument was used by the British and Americans to block French proposals for separating the Rhineland from Germany. They saw that the French loss of Alsace and Lorraine to Germany after the Franco-Prussian war of 1870 had stimulated French hopes for revenge which had contributed to the causes of World War I. The British and Americans were determined that the Rhineland should not become a new Alsace-Lorraine for German nationalists. But the Allied understanding of potential causes of an aggressive nationalist revival in Germany seems to have been limited to the irritating effects of lost provinces and other territories where ethnic kinsmen are minorities in another nation. The Allied leaders do not seem to have recognized the possibility that the war-guilt clause and the reparations bill might be just as dangerous.

Keynes's critique of the treaty terms focused on the reparations bill. He argued that, when the Allies gathered to write a bill of damages that they would award to themselves, they followed their natural interests to maximize the assessment for which the Germans would be held liable. The result was a bill of damages that was too large to include in the treaty itself, but by 1921 was assessed at 132 billion gold marks, consistent with what Keynes predicted (1920, pages 160161). (A gold mark was defined as the amount of gold that a mark bought before the war, so there were about 4 gold marks per US dollar or 20 gold marks per British pound.) Keynes argued that, behind the Allies' noble rhetoric about a nonpunitive peace, they had presented a bill that could only be paid by the virtual enslavement of the German people, who were already exhausted by the long war. By comparison, the pre-war annual national income of Germany had been estimated as about 40 billion marks (Mantoux, 1946, page 113), and the German government during the four years of World War I had incurred a national debt of about 140 billion marks (Kolb, 1988, page 40).

Keynes's analysis is a compelling mixture of detailed analysis of economic prices and quantities, together with briefer but remarkably insightful political commentary. At the end of his second book on the treaty, Keynes (1922, page 198) recommended his own alternative plan: that Germany should be required to pay 1.26 billion gold marks per year for 30 years. 
The actual reparations requirements were gradually reduced towards Keynes's recommendation during the 1920s. The original 1921 Reparations Commission expected Germany to pay about 3 billion gold marks per year. The Dawes plan in 1924 foresaw annual payments of about 2.5 billion marks per year, and the Young plan in 1928 reduced the amount to an average of about 2 billion reichsmarks per year over 59 years (see Kolb, 1988). Adjusting for price level, the reichsmark in 1928 has been compared in value to about 2/3 of a 1913 gold mark (Mantoux, 1946, page 115), so the Young plan seems to be close to Keynes's recommendations of 1922.

In his defense of the reparations provisions, Lloyd George (1938, page 437) argued, "The liability to pay compensation for damage done by a wrong-doer, and the payment by the defeated suitor of the costs incurred in a vindication of justice are among the integral principles of law in every civilized community. States are not immune from the application of that elementary doctrine of jurisprudence." He also argued that the Germans were clearly the aggressors in 1914 (ignoring German claims that aggressive Russian mobilization was to blame), and he cited historical precedents of reparations, including large reparations payments by France in 1815 and 1871. Furthermore, against Keynes's claims that the Versailles reparations bill was impossible to pay, Lloyd George argued that the treaty never assumed that all assessed damages had to be paid: "A still more important provision is that contained in Article 234. Germany was not to be compelled to pay in full the damages assessed, or the instalments fixed under Article 233, if she could demonstrate that it was beyond her capacity to meet the obligations." (Lloyd George, 1938, page 511.) Thus, the revisions of the Dawes and Young plans were an essential part of the planned implementation of the treaty of Versailles, according to Lloyd George. He expressed great regret, however, that the departure of the Americans from the Allied councils allowed the harder French line to dominate the Reparations Commission in the early 1920s, before the Americans returned in the Dawes Commission (Lloyd George, 1938, pages 512-513).

Lloyd George's legal argument seems to miss the point that reparations accrue to the winners of war, which is a test of strength, not of justice. Regardless of who were the aggressors in 1914, the Germans were being required to pay reparations in 1919 only because they had lost the war. Thus, although the principle that the loser in a court of law pays to the winner may deter unlawful behavior, a principle that the loser in a war pays to the winner does not deter the strong 
from starting wars.

Etienne Mantoux, the son of a French diplomat, wrote a passionate critique of Keynes, which was published after Mantoux's death in the final days of World War II. Mantoux (1946) blamed Keynes for helping to undermine the implementation of the treaty of Versailles. Following Keynes's influential critique, the Americans decided not ratify the treaty, and the British developed a sense of guilt which prevented them from supporting enforcement of any sanctions against German noncompliance.

From the perspective of the early 1940s, Mantoux also saw serious flaws in Keynes's economic analysis. In the 1930s, Hitler's military program spent about 15 billion reichsmarks per year, substantially more than the reparation demands that Keynes had thought so excessive. After 1940, when the boot was on the other foot, Mantoux estimated that the Germans took at least 15 billion reichsmarks per year from the countries that they had defeated and occupied. (See Mantoux, 1946, pages 115 and 123-126. Correcting for price-level changes, the reichsmark of 1937 has been equated in value to about 0.8 gold-marks of 1913 in the national income accounting of Mantoux.)

\section{Reparations and German politics}

The arguments of Keynes, Lloyd George, and Mantoux all seem to miss the fact that the most important consequence of the Allied reparations policy was its chronic poisonous effect on German politics.

At various points in the Allied discussions on the reparations question, people raised the objection that, if German reparations really meant massive free imports from Germany, then Allied governments should be worried about the financial disruption and unemployment of their own workers whose products would be displaced by German goods. Even before the war, a popular book by Norman Angell (1913) argued that such disruptions would make indemnities futile for the victors of future wars (see also a critical discussion by O'Farrell, 1913). In his answer to this objection, Keynes (1922, pages 163-166) argued that such displacement would be only a short-term phenomenon, and so its effects could be mitigated by spreading out the reparations transfers over a long period of time. This economic consideration seems to be Keynes's basic rationale for the idea that the reparations payments should be spread out over a 
period of 30 years.

Lloyd George reports that, in the Allied plans for the peace treaty, the first suggestion that a reparations indemnity should be spread over a long term of years actually came from a memorandum that was written in 1916 by Keynes and W. J. Ashley (reprinted in Johnson, 1971, pp. 313-334). Commenting on the analogous German contingency plans for a war indemnity in the event of their own victory, Lloyd George (1938, page 448) notes that the Germans had planned to seize valuable assets and colonies, "but they had not hit upon the idea of levying a tribute for 30 to 40 years on the profits and earnings of the Allied peoples. Mr. Keynes is the sole patentee and promoter of that method of extraction." Actually, Keynes's 1916 memorandum attributes the idea to an 1874 publication of Adolph Wagner of Berlin, who observed that the pernicious effects in produced in Germany by the payment of the French indemnity of 1871 could have been partly avoided by spreading the indemnity over a longer period.

But there is a contrary political argument for limiting reparations to what can be taken in a very few years: Lengthening the period of reparations payments means lengthening the period during which the Allies would need to continually threaten Germany, to compel payment. The difficulty with such long-term threats is widely appreciated among game theorists today, since Abreu $(1986,1988)$ showed how short-term punishments can be more effective because the prospect of being welcomed back into a state of grace can give the victim an incentive to participate in his own punishment. The difficulty of extracting long-term repayment from a sovereign debtor is now recognized as an fundamental constraint in international finance (Bulow and Rogoff, 1989). When the history of German reparations is viewed from the perspective of modern sovereign-debtor analysis, much of the sad history becomes clearer. Keynes and his contemporaries tended to focus on the question of Germany's capacity to pay, but Ritschl (1999) argues from a modern perspective that the debate should have been about Germany's incentive to pay. Thus, Ritschl (1999) notes that the core reparation demands made the national debts of Germany, France, and Britain look similar as proportions of their respective national incomes in 1920, but Germany in 1920 would have had less substantially incentive to pay any given foreign debt amount because its overseas assets had already been seized after the war.

Keynes was not oblivious to the long-term enforcement problem. His 1916 memorandum originally suggested that a German colony might be held as security for indemnity payments, but 
it is hard to imagine Germany paying a large reparations bill just to regain the privilege of administering Tanganyika. After the massive reparations bill was unveiled, Keynes (1922, page 169) asked, "Who believes that the Allies will, over a period of one or two generations, exert adequate force over the German government... to extract continuing fruits on a vast scale from forced labor?" In the end, however, Keynes (1922, page 198) set this argument aside and followed the economic argument to recommend that reparations should be paid over a period of 30 years. The only way to reconcile the above quote with Keynes's actual prescription for 30 years' reparations payments seems to be that he was assuming that the enforcement problem would disappear once the annual debt burden was reduced to a manageable size that would not require "forced labor".

The treaty of Versailles stipulated an occupation of the Rhineland for a period of 15 years, which was shorter than the timetable for reparations. Furthermore, it was well known that French hoped to use the occupation period for cultivating a separatist political movements in the Rhineland, so that the prospective reunion of the Rhineland with Germany was questionable even if Germany made all the reparations payments. When we recognize this two-sided credibility problem, possible schemes become apparent. Perhaps the Rhineland might have been divided into smaller districts, with one district for each year of the reparations schedule, and the Allies could have promised to evacuate each district after Germany fulfilled its required payments for the corresponding year. But no such game was proposed in the 1920s. The prospect of an accelerated Allied withdrawal from the Rhineland after the 1925 Locarno pact may have provided an incentive for German fulfillment of reparations payments in the later 1920s, but this withdrawal was completed in 1930. Thus, except perhaps in the period 1925-1930, the Rhineland occupation was not used as an incentive for reparations payments.

If the threat of economic sanctions against Germany was supposed to motivate the reparation payments, then anyone familiar with subgame perfection in game theory would ask how the costs of such sanctions on Germany would compare to their cost of paying the debt. I have found no contemporary attempt to estimate what such Allied economic sanctions would have cost Germany. Ritschl (1999) argues that German fulfillment policy after 1924 was substantially motivated by a desire to maintain Germany's credit for international commercial transactions; but this motivation was coupled with a belief that the reparations bill might be 
reduced or canceled in the near future under American pressure, especially when powerful American bankers had a stake in German credit. Reparations under the Dawes plan (1924-1929) were paid with money that the Germans borrowed from Americans (McNeil, 1986), which would be rational for both sides if they believed that such cancellation might be immanent. (It was generally understood that America could induce Britain and France to cancel the reparation debt by forgiving their wartime debts to America.) But in the end, the American government was not induced to arrange such debt cancellation until 1932, after the onset of the Great Depression and the rise of Nazism.

Thus, we are left to conclude that the motivation for Germany to pay its reparation debt depended substantially on an Allied threat of military force. This simple fact was commonly left unmentioned in the discussions of reparations policy (the above quote from Keynes being one of the rare exceptions). So the reparations plan meant that, for an entire generation, Germans would be paying a substantial fraction of their national income every year as a result of threats of foreign military invasion. When we recognize this fact, it seems obvious that the reparations would make militaristic nationalism seem more attractive to the German people.

Although reparations were the norm after previous wars, there seems to have been no precedent for such a long-term reparations policy as was attempted after World War I, except in those cases where the victorious power occupied and colonized the defeated nation. After the Franco-Prussian war, France was required make payments worth 200 million British pounds within three years, during which time the German army would occupy northern France as security for the debt. To hasten the withdrawal of German troops, France actually paid this indemnity well before the required deadline. To raise the funds for this payment, the French government sold bonds, which of course still had to be repaid over many years. But these longterm bond payments did not stimulate nationalist controversy after 1872, because the bonds were considered to be legitimate property and were largely held by French citizens.

In effect, we are claiming here that a long-term debt contract between the French government and French citizens was easier to enforce than a long-term debt contract for the same amount from the French government to the German government. There may be something paradoxical about this claim, because the German government had an army to compel compliance while the French bond-holders did not. Part of the justification for this claim is that 
the French bond-holders could vote in France. Furthermore the bond-holders would have included a large share of the most wealthy French citizens whose political influence would be greater than their votes. (See North and Weingast, 1989, and Dixit and Londregan, 2000, for more on the credibility of debts to politically active bondholders.) But this claim can also be further justified by observing that, when the bondholders' claims were considered legitimate by French citizens, the debt's repayment could be sustained by the general social mechanisms for protection of property rights in France, even if an effective majority of French voters held were not bondholders, and indeed even if many of the bondholders were foreigners.

This crucial point deserves more detailed analysis, so let us sketch a simple model here. The citizens of any modern society rely on their political leaders to guarantee broad protection of property rights, which is essential for modern economic growth (North, 1981). We may assume that any political leader enjoys the privileges of his high position, but the protection of any citizen's rights might require some costly effort from the leader. So he would enjoy his position even more if he could hold it without bothering to protect anybody's rights. In the competitive political system, however, a leader can hold his position only when he has the support of some large group of citizens, and each citizen always has a choice of many politicians to support. In such a system, a reputational equilibrium in which political leaders always work diligently to protect property rights can be sustained as follows: If any leader ever failed to protect any legitimate right, then nobody would trust him to protect anyone else's rights in the future, and so this leader would lose all his supporters, and he would lose his leadership position to another politician with a better reputation for protecting property rights. Once a leader expected that nobody would ever support him in the future, no matter what he does, then he would indeed have no incentive to exert any costly effort for protecting anybody else's rights. So the citizens' distrust would become a rational expectation.

Notice that a linkage between different political actions is essential in such an equilibrium. A leader's perceived failure to protect any one person's rights must make all potential supporters fear that he will similarly fail to protect their rights. In such an equilibrium, citizens' distrust could even be stimulated by the leader's failure to protect foreigners' rights. But the linkage between these different "failures" is effective only to the extent that it is recognized by the citizens whose support the politician needs. Thus, multiple equilibria may exist, 
depending on what the citizens consider to be "legitimate" rights that a trustworthy leader is supposed to protect. When there is a question of paying reparations to foreigners, there can be an equilibrium in which nonpayment would be perceived as a failure to protect foreigners' rights that would make everybody distrust the current leader. But there can also be an equilibrium in which payment of reparations with taxpayers' money would be perceived as a failure to protect taxpayers from illegitimate extortion, so that everybody would distrust the current leader, and his political career would be destroyed. Thus, even when the size of the debt and the value of annual national income and the value of national assets held abroad are all given, still the perceived legitimacy or illegitimacy of a reparation debt could be the critical factor that determines whether national leaders should rationally repay it.

An argument based on one equilibrium in a game that has many different equilibria may seem arbitrary. But the game that we are considering here is a model of the fundamental political process that underlies all enforcement of property rights. This game must have multiple equilibria, or else property rights could not be transferred simply by paper transactions. So the concept of legitimacy that defines how leaders may lose public trust is not just part of an equilibrium, it is an essential aspect of the great equilibrium that underlies modern economic growth. Any modern society must have formal procedures for certifying debts as legitimate property of the debtors. Thus, the French government was able to market its 1872 indemnity bonds in such a way that the bondholders' rights were recognized as legitimate property rights by all French citizens, and so their repayment was never in doubt.

In contrast, the Allies after World War I were never able to convert their reparation demands against Germany into any form that would be accepted as legitimate by the citizens of Germany. In such a context, any payment of reparations with German taxpayers' money would be perceived as a failure to protect Germans from illegitimate extortion, which would destroy public trust in their leaders. Until the distrusted leadership was replaced, social violence could be expected to increase disastrously. Thus we can see why the German people reacted against the reparations payments in a way that they would not have against a similar debt that they considered legitimate. The Allies' attempt to force Germans to accept the legitimacy of the reparation debt, by the war-guilt clause in the treaty of Versailles, only compounded the problem by linking the debt to what was viewed in Germany as an insulting falsehood. 


\section{Incentives for the Great Depression and the rise of Nazism}

As we have seen, the Allied reparations policy at Versailles was to set an impossible reparation debt according to self-defined judicial principles, and then to offer magnanimously to scale the debt down to match Germany's ability to pay. But this policy of repeatedly testing Germany's ability to pay had an insidious effect on German economic policy, because Germany could avoid reparations payments when it was in economic distress. In effect the Allies were imposing a high marginal tax rate on German prosperity, which reduced the German government's incentive to avoid economic calamities like hyperinflation and depression.

The deflationary policies that led Germany into the Great Depression followed the general advice of the Allied Reparations Agent, Parker Gilbert (McNeil, 1986, pages 165-176). To finance reparation payments, Germany would require a surplus of exports over imports in international trade, in spite of other countries' protectionist policies. Under the Dawes plan, Gilbert was authorized to help Germany by deferring the conversion of reparation payments from reichsmarks into Allied currencies, and so a devaluation of the reichsmark would create a charge against Gilbert's stewardship of Allied funds. This fact may have given Gilbert a personal incentive to urge that Germany should achieve the required trade surplus without any devaluation of the reichsmark. Fears of inflation also deterred most German politicians (except the Nazis) from advocating devaluation (Borchardt, 1984). Thus, the trade surplus could be achieved only by deflationary policies that would reduce German wages. German leaders were aware of the social strife that would accompany such a broad reduction in wages, but they also saw that the best way to prove that Germany could not pay reparations would be by following the economic advice of the Allied Reparations Agent as it led into the Great Depression.

It may seem hard to believe that Germany's leaders would deliberately plunge their economy into the worst depths of the Great Depression (with $40 \%$ nominal loss of national income and over 30\% unemployment) to avoid the reparations burden. At the time, there could always be hope that the worsening economic situation might soon induce America to cancel the debts. In a dynamic war-of-attrition game, where each side is always uncertain about whether another day of conflict might finally induce the other side to yield some valuable prize, the actual cost of the conflict is a random variable that may be more (or less) than the prize. But a crude calculation could actually suggest that the Great Depression, as a way of escaping the reparations, 
might not have been such a bad investment for Germany. According to the national income figures cited by Mantoux (1946, page 115), the total real loss of German national income from the 1929 peak until this level was regained after 1935 can be estimated as worth about 40 billion gold-marks (using Mantoux's price-adjustment factors to convert back to 1913 units of account). This total loss is still substantially less than the 132 billion gold-marks that the Allies originally demanded in their reparations bill.

The Young plan of 1928, which reduced German obligations close to the level that Keynes had advocated, did not improve the situation, but instead set the stage for the Nazis. Accepting the Young plan offered the Germans a substantial reduction of the debt burden and a withdrawal of all Allied forces from the Rhineland, in exchange only for a solemn promise that Germany would pay the reduced reparation debt. In an attempt to protect the leaders who accepted this deal for Germany, a supermajority coalition for accepting the Young plan was negotiated in the Reichstag. But then, with all mainstream parties endorsing the Young plan, the extreme right led by the Nazis became the only political group that could exploit popular feeling against the plan. The Weimar constitution allowed a petition signed by $10 \%$ of the voters to force a national referendum on the treaty. In the campaign for this referendum, the Nazis obtained their first national prominence outside of Bavaria. Although less than $14 \%$ of the electorate voted for the referendum, the Nazis gained respect as the main political organization to repudiate the reparations.

The withdrawal of Allied troops from the Rhineland after 1930 also made it safer for Germans to take more extreme nationalist positions without fear of immediate attack from Allied armies. So under the Young plan, the Germans had made a solemn contract to pay reparations, but the sanctions against nonpayment were disappearing. Under such circumstances, it is not surprising that many people wanted to give power to the kind of extremist leader who would be willing to abrogate solemn contracts. The Nazis gained $18 \%$ of the vote in the 1930 Reichstag elections.

It is striking that the first presidential government under Bruening began in 1930 shortly after the ratification of the Young plan. By waiting to take power until after the ratification, Hindenburg could evade much of the responsibility for accepting the treaty. But thereafter Bruening subordinated domestic economic policy to the goal of liberating Germany from the 
burden of reparations (Kolb, 1988, page 114). If economic suffering itself would not induce the Allies to remove the reparations burden, then the rising popularity of the Nazis among destitute Germans in the depths of the depression could be a more convincing threat. And indeed, the Allies finally agreed to cancel all reparation debts (and the Americans agreed to suspend interAllied war debts) in 1932, after the Nazis had gotten over $37 \%$ of the vote in Presidential and Reichstag elections.

One counter-argument against a theory that blames the reparations for Hitler's conquest of Germany is that Hitler did not take power until January 1933, but the reparations were canceled in July 1932, and Germany was granted equality of armament rights in December 1932. Even assuming that conservative leaders of Germany had an incentive to cultivate the Nazis during these international negotiations, why would they allow Hitler to take over afterwards? The answer is that the Great Depression and the street armies of the Nazis had been cultivated over a several years, and they could not be wished away in a few months. So the need to tame the Nazis and restore order drove Hindenburg to try desperate tactics: first the July 1932 coup which nationalized the Prussian government, and then the negotiation of a coalition cabinet that included Hitler as chancellor in January 1933.

We may view the events of 1930-1933 as a signaling game between the Allied leaders and the conservative leaders of Germany. (See also Arce M, 1995.) The German leaders' "type" was one that would be willing to accept a risk of a Nazi takeover rather than pay reparations, but the Allied leaders were not convinced of this type until they saw the German leaders let the Nazis grow strong enough that a Nazi takeover had actually become a positive-probability event. Thereafter, the realization of a Nazi takeover depended on random factors that were beyond the knowledge of the Allies and the conservative leaders of Germany. In the actual outcome, the most important of these factors may have been the often underestimated talent and the ruthlessness of the Nazi leadership.

In particular, the conservative leaders of Germany underestimated the effectiveness with which Hitler would use the position of chancellor. When Hitler was at the top of the government, there was suddenly an understanding that no political opponent could protect himself from Nazi violence, and thus was created a terrible new social equilibrium in which the institutions of Weimar had no further role. 
In such a signaling-game model of the end of the Weimar Republic, the assumption that leaders of one nation could have incomplete information about another nation is critical and deserves a bit more scrutiny. If the German "type" in this story has any meaning, then it is something that was derived from the political preferences of hundreds of elite leaders and millions of citizens. So one might ask why uncertainty about this type could not be easily resolved just by taking a trip to Germany and talking to people there. Of course, nations maintain diplomatic missions and espionage networks to get exactly this kind of information. But in matters of international relations, the advantages of strategic misrepresentation are well understood by common citizens as well as national leaders. Social norms against fellow citizens who publicly express national weakness and susceptibility to foreign pressure are as essential to national survival as the social norms that sustain property rights are to prosperity. A society that lacked such patriotic norms would not long retain an independent national identity. And such norms were particularly well developed in the European nations after World War I, when each had spent four years suppressing expressions of national exhaustion, in hopes that the other side would give up first.

Furthermore, given the imperative for democratic leaders to be consistent with their citizens' understanding of legitimate property rights, information about the type of either side would not be effective until it was convincingly communicated to millions of people on the other side. For a nation to be strong in the international arena, its citizens must share a wide consensus on questions of legitimacy, but this need for consensus within a nation makes it more difficult for its citizens to admit that other concepts of legitimate rights might prevail in other nations. From this principle, we may begin to see how the Allied nations and Germany could be so persistently separated by fundamentally inconsistent notions of international justice.

\section{Poland and the Rhineland}

The end of Weimar was not quite the end of Versailles. In 1933 the German Rhineland was still demilitarized, and the eastern boundary of Germany still lay where it had been placed according to the treaty of Versailles.

Even among democrats in Germany there was deep resentment against the cession of German territory to the new state of Poland. Max Weber himself expressed in 1919 the hope that 
"the first Polish official that dares enter Danzig will be met by a bullet" (Mommsen, 1984, page 312). Thus, even under a democratic Germany there would have been a problem of deterring German attempts to revise its eastern boundary, and so the problem of guaranteeing Poland's security was a clear and fundamental concern of the Allies at Versailles.

This problem was solved at first by German disarmament, until 1932 when the Allies granted Germany's right to rearm. But even then, an invasion into the unoccupied Rhineland would have been cheap and easy for the French army and very costly for the Germans. Hitler might have lost the support that he still needed from military leaders and others if his aggressive policies were seen as costing Germany the Rhineland. So as long as the Rhineland was demilitarized, the Allies had a credible threat of invasion to deter Germany from aggression against Poland.

But after Germany reoccupied the Rhineland in March 1936 and reestablished defenses on its western boundary, the Allies had no threat to deter aggression in the east against Poland, other than a major war which they were unlikely to enter unless they saw their own national security at risk. As Kagan (1995, page 417) argues, "It might never have been possible to deter the fanatical Hitler from war but Germany could have been prevented from launching any serious adventure down to the occupation of the Rhineland." Thus Kagan concludes that the Allied acquiescence to Hitler's reoccupation of the Rhineland was the last crucial step in the destruction of the Versailles peace.

This logical connection between the Rhineland and Poland can be recognized as a straightforward exercise in sequential rationality. Once we learn to look for credible threats, we can see how the Allies might have benefitted from returning Germany's overseas colonies in 1919, so as to create other vulnerable German possessions that could be easily taken if Germany moved against Poland.

The fundamental requirement for credible threats to defend boundaries is a central theme of Schelling (1960), and it has been widely appreciated thereafter among international relations theorists. But in 1936 the leaders of Britain and France overlooked this logic. Thereafter, Poland was trapped between two hostile giants, and the expansion of Nazi Germany could not be stopped until Britain and France faced a very real threat of their own national destruction. 


\section{Conclusions}

In our brief review of this complex history, we have tried to show how a modern strategic analysis might have helped people to think more carefully about the institutional systems that were established by the Weimar constitution and the Versailles treaty. Our analysis of the Weimar constitution suggests that its combination of a strong presidency with a proportionalrepresentation legislature may have been be responsible for the breakdown of German parliamentary government in 1930, and may also have in some ways facilitated the careers of extremist authoritarian politicians. But we could not argue that the rise of Nazism itself was directly caused by any flaws in the Weimar constitution. In our analysis, the rise of Nazism is seen more as a consequence of the flaws in the Versailles treaty. In particular, the Allies' huge reparations bill created a long war of attrition that encouraged Germans to cultivate the Great Depression and threat of Nazi dictatorship.

Reading Keynes's books on the treaty of Versailles today, it sometimes seems that he could foresee all of the sad history of the next two decades, but the breadth and incisiveness of his observations failed to extend into his analysis. In particular, Keynes clearly described the long-term political dangers of prolonging reparations payments over decades, and yet he ultimately disregarded these dangers and based his recommendations instead on countervailing considerations of short-term economic difficulties. Being trained as an economist to study market phenomena, his analysis would naturally put more weight on economic factors than on political considerations. The central thread of his arguments always focused on prices and quantities of goods and services, and political insights which did not fit into the conceptual framework of price theory tended to get lost in the end. But since Keynes's time, the boundaries of economics have changed and the analytical scope of economic study has grown beyond price theory and analysis of markets, so that economists can now focus more broadly on analysis of incentives in all social institutions.

From today's perspective, the failure of leading thinkers to systematically question the sequential rationality of proposed reparations policies in 1919 seems shocking. Since Selten $(1965,1975)$, students of economics have learned to analyze subgame-perfect and sequential equilibria in games with threats and promises. The importance of looking down the game tree and evaluating the sequential rationality of policies and agreements is particularly well 
appreciated in the analysis of international relations. Keynes's focus on the question of Germany's ability to pay now seems seriously misleading. As Ritschl (1999) has emphasized, economists today know that we should focus more on the question of Germany's incentive to pay.

It is common today to explain economic failures and inefficiencies as being results of costly signaling in situations where decision-makers have incomplete information about each other. So from this perspective, it is natural to suggest that Allied uncertainty about Germany's type could explain why the Allies followed a policy that would forgive the reparation debt only after Germany had clearly incurred great economic sacrifices and had developed a serious threat of nationalist extremism. That is, we can rationalize the counterproductive Allied policy by assuming that, before 1932, the Allies assigned a low subjective probability to the event that leaders of Germany were the type that would choose to exacerbate the depression and cultivate the Nazi fringe when it was the alternative to paying reparations. Given the actual depth of German antipathy to the reparations, we can then see the German leadership as responding rationally to the incentives created by the Allies policies.

So a student of modern information economics may naturally see incomplete information about other nations' political realities as a critical part of the problem faced by the peace-makers in 1919. It is this perspective that enables us to see the lack of German representation in the peace conference as one of the crucial mistakes in the twentieth century. A personal relationship between statesmen at a summit conference can increase their ability to trust each other's communication, although obviously there must be limits to trust in this communication channel as well. Presumably the Allies' decision to exclude Germany from the peace conference was motivated by an understanding that the some aspects of the information that German representatives could offer would be misrepresented strategically to benefit German interests. But the alternative was to defer communication until later, when the problem of misrepresentation would still exist but the established framework of the treaty would leave diplomats much less flexibility to rectify the treaty's flaws. In particular, the war guilt clause stands out as a provision in the treaty that could have been abandoned by the Allies at relatively little cost if they had understood, before the treaty was finalized, how costly this clause would be to German democratic leaders.

A social scientist may also hope that better conceptual structures for analyzing social and 
political phenomena could have improved the Allies' understanding of German political realities. We have argued here that German attitudes towards the reparations could have been understood by considering a simple model of how political leaders are induced to offer general protection of property rights, which is now widely recognized as a question of fundamental importance in modern economic history (North, 1981).

Game-theoretic models of politics now give us an analytical methodology for trying to predict how specific constitutional provisions, which determine the rules of the political game, might systematically affect political behavior. With the passage of time and the spread of democracy, we also now have much more data about a variety of democratic institutions than Weber had in 1919. Thus, we should be in a better position to evaluate the extent to which the failure of the Weimar Republic may have been caused by problematical features of its constitutional structure.

In this regard, the focus has been on the critical breakdown of parliamentary government in the Weimar Republic before the rise of the Nazis. It has been suggested that this breakdown may have been partly caused a kind of ideological rigidity that was encouraged by the structure of the political game established by the Weimar constitution, with its strong presidency and highly proportional legislature. But we do not really have a comprehensive theory of how democratic constitutional structures influence politicians' rational choices about whether to offer themselves as rigid ideological advocates or as flexible opportunistic representatives. So this suggestion is at best a conjecture, needing much more careful scrutiny with game-theoretic models and analysis of empirical data.

If such constitutional structures contributed to the Weimar disaster, then it is clearly important for us to try to understand such effects. For example, the 1993 Russian constitution has some important similarities with the Weimar constitution, including presidential decree powers which are even stronger than those that seemed problematical in the Weimar Republic (Carey and Shugart, 1998). To contribute usefully to public debates on such constitutional structures, scholars need a theory of constitutional analysis that can help them to identify possible consequences of specific democratic structures. When objective theories are lacking, the principal voices in such debates are likely to be those of professional politicians, whose constitutional preferences may depend mostly on their short-term perceptions of how to best 
restructure the political game to their own immediate advantage. The theoretical and empirical literature on analysis of constitutional structures is growing, but it is still small and much work remains to be done to develop a useful and comprehensive theory of democratic institutions.

The world is complex, and no academic model can give a definitive answer to any serious question of social policy. What our social theories and models can do, and must do, is help us to recognize more systematically the possible consequences of different social policies, so that the possibility of these consequences should not be neglected in public policy debates. For this purpose, we need analytical tools that are flexible and broad in scope. Scholars who are trained only in the analysis of markets are more likely to overlook consequences that are political in nature. And consequences that involve a complex interaction of both political and economic phenomena, like the effect of Allied reparations policy on German political leaders' incentive to sabotage their own economy, are less likely to be overlooked when we have general analytical methodologies that span economic and political systems. In this direction at least, economics has grown and social theory has advanced significantly since the time of Weber and Keynes. But much more work needs to be done to develop an understanding of political and economic institutions that can help make the next century not only more prosperous, but also more democratic and more peaceful than the last.

\section{REFERENCES}

D. Abreu, 1986. "Extremal equilibria of oligopolistic supergames." Journal of Economic Theory 39:191-225.

D. Abreu, 1988. "On the theory of infinitely repeated games with discounting." Econometrica 56:383-396.

N. Angell, 1913. The Great Illusion (London: W. Heinemann).

D. G. Arce M., 1995. "The economic consequences of the peace: Keynes and correlation," Mathematical Social Sciences 29:263-276.

K. Borchardt, 1984. "Could and should Germany have followed Britain in leaving the gold standard?" Journal of European Economic History 13:471-498.

H. Bruening, 1970. Memoiren 1918-1934 (Stuttgart: Deutsche Verlags-Anstalt).

J. Bulow and K. Rogoff, 1989. "A constant recontracting model of sovereign debt," Journal of 
Political Economy 97:155-178.

J. M. Carey and M. S. Shugart, 1995. "Incentives to Cultivate a Personal Vote: A Rank Ordering of Electoral Formulas." Electoral Studies 14:417-439.

J. M. Carey and M. S. Shugart, 1998. Executive Decree Authority (Cambridge: Cambridge University Press).

A. Cole and P. Campbell, 1989. French Electoral Systems and Elections since 1789 (Aldershot: Gower).

A. Dixit and J. Londregan, 2000. "Political power and the credibility of government debt," Journal of Economic Theory 94:80-105.

E. Johnson, editor, 1971. "Preparatory work on peace terms, 1916-1919," in The Collected Writings of John Maynard Keynes, Volume 16 (London: MacMillan), pp 311-386.

M. P. Jones, 1995. Electoral Laws and the Survival of Presidential Democracies (Notre Dame: University of Notre Dame Press).

D. Kagan, 1995. On the Origins of War (New York: Doubleday).

J. M. Keynes, 1920. The Economic Consequences of the Peace (New York: Harcourt, Brace, and Howe).

J. M. Keynes, 1922. A Revision of the Treaty (New York: Harcourt Brace).

J. M. Keynes, 1936. The General Theory of Employment, Interest, and Money (New York: MacMillan).

E. Kolb, 1988. The Weimar Republic, translated by P.S. Falla (London: Unwin Hyman).

H. W. Koch, 1984. A Constitutional History of Germany (New York: Longman).

D. Lloyd George, 1938. The Truth about the Peace Treaties (London: Gollancz).

E. Mantoux, 1946. The Carthaginian Peace, or the Economic Consequences of Mr. Keynes (London: Oxford University Press).

J.-M. Mayeur and M. Riberioux, 1984. The Third Republic from its Origins to the Great War 1871-1914, translated by J. R. Foster (Cambridge: Cambridge University Press).

W. C. McNeil, 1986. American Money and the Weimar Republic (New York: Columbia University Press).

W. J. Mommsen, 1984. Max Weber and German Politics, translated by M. S. Steinberg (Chicago: University of Chicago Press). 
D. North, 1981. Structure and Change in Economic History (New York: Norton).

D. North and B. Weingast, 1989. "The evolution of institutions governing public choice in 17th century England," Journal of Economic History 49:803-832.

H. H. O'Farrell, 1913. The Franco-Prussian War Indemnity and its Economic Results (London: Harrison).

J.-P. Rioux, 1987. The Fourth Republic, translated by G. Rogers (Cambridge: Cambridge University Press).

A. Ritschl, 1998. "Reparations transfers, the Borchardt hypothesis, and the Great Depression in Germany, 1929-1932: a guided tour for hard-headed Keynesians." European Review of Economic History 2:49-72.

A. Ritschl, 1999. "Les réparations allemandes, 1920-1933: une controverse revue par la théorie des jeux", Economie internationale 78:129-154.

R. Selten, 1965. "Spieltheoretische Behandlung eines Oligopolmodells mit Nachfragtragheit," Zeitschrift fuer gesampte Staatswissenschaft 121:301-324, 667-689.

R. Selten, 1975. "Reexamination of the perfectness concept for equilibrium points in extensive games," International Journal of Game Theory 4:25-55.

M. S. Shugart and J. M. Carey, 1992. Presidents and Assemblies (Cambridge: Cambridge University Press).

T. C. Schelling, 1960. The Strategy of Conflict (Cambridge, MA: Harvard University Press).

R. Taagepera and M. S. Shugart, 1989. Seats and Votes (New Haven: Yale University Press).

[The definitive published version of this paper is in Journal of Institutional and Theoretical Economics 160 (2004), 187-209.] 